\title{
Evaluation of the Impact of Computer-Assisted Instruction on Mathematics and Physics Students' Achievement: Implication for Industrial Technical Education
}

\author{
Eunice N. Onah ${ }^{1}$, Christian S. Ugwuanyi ${ }^{2,4}$, Chinedu I.O. Okeke ${ }^{3}$, Boniface G. Nworgu ${ }^{4}$, Uche V.N. Agwagah ${ }^{4}$, \\ Chika C. Ugwuanyi ${ }^{4}$, Pauline I. Obe ${ }^{5}$ Mercy N. Nwoye ${ }^{*} \&$ Agnes O. Okeke \\ ${ }^{1}$ Department of Computer and Robotic Education, Faculty of Vocational and Teacher Education, University of Nigeria, Nsukka \\ ${ }^{2}$ Postdoctoral fellow, School of Education Studies, Faculty of Education, University of the Free State, Bloemfontein, 9300, Sou th Africa. \\ ORCID: 0000-0003-2174-3674 \\ ${ }^{3}$ Host, Professor and Head, School of Education Studies, Faculty of Education, University of the Free State, Bloemfontein, 9300 , South Africa. \\ ORCID: 0000-0003-3046-5266 \\ ${ }^{4}$ Department of Science Education, Faculty of Education, University of Nigeria, Nsukka.
}

${ }^{5}$ Department of Industrial Technical Education, Faculty of Vocational and Teacher Education, University of Nigeria Nsukka.

\begin{abstract}
Twenty-first century classrooms have come with a lot of changes in the instructional delivery at various levels of education. However, most teachers in Nigerian still adopt the traditional method of instruction not minding the demands of the twenty-first century classrooms. As a result of this, there is dearth of empirical evidence on the impact of computerassisted instruction on the students' achievement in mathematics and physics. This study, therefore, evaluated the impact of computer-assisted instruction (CAI) on mathematics and physics students' achievement. Quasi-experimental, nonequivalent groups design was adopted for the study using a sample of 200 participants. Mathematics Achievement Test (MAT) and Physics Achievement Test (PAT) were used to collect data for the study. The internal consistency reliability indices of the MAT and PAT were estimated as 0.89 and 0.75 respectively using Kuder-Richardson formula 20. The hypotheses were tested at 0.05 levels of significance using analysis of covariance. It was found that Computer-Assisted Instruction (CAI) significantly improved mathematics and physics students' achievement. This finding has implication for Industrial Technical Education for the fact that improved achievement of students in mathematics and physics subjects at secondary education level will enable them to have interest in industrial technical education at higher education. Thus, Mathematics and Physics teachers should be trained on how to master the techniques needed for the preparation and use of the CAI package for effective teaching and learning of different concepts in Mathematics and physics.
\end{abstract}

Keywords: Achievement, Computer Assisted Instruction, Evaluation, Impact, Mathematics, Physics

\section{INTRODUCTION}

The rate of students' poor performances in mathematics and physics in external examinations in Nigeria is becoming a

*Corresponding author

Email: ngozi.nwoye@unn.edu.ng disturbance to educators of Mathematics and Physics and calls for immediate attention. Over the years, the students' achievement in the sciences, most especially in physics has been below expectations (Akanbi et al. 2018; Ugwuanyi et al. 2019a). The performances of students in Mathematics and Physics are abysmally low (Usman, 2002; Onah, 2004; West African Examination Council [WAEC], 2006, 2007, 2012; Kolawole, 2012). Ugwuanyi et al (2020a) found that not minding the role of mathematics in the Nigerian education system, students' performance in both external and internal examinations is on the downward trend. On this, Amoo (2002) stated that many problems are encountered in the teaching and learning of mathematics and science subjects in Secondary Schools. In the years 2008, 2009, 2010 and 2011, the percentage pass in mathematics with credit and above in Nigeria were $23.00 \%, 31.00 \%, 24.94 \%$, and $38.98 \%$ respectively (Azuka, 2013). Dike (2013) also observed that candidates recorded a mass failure in the Nov/Dec 2013 WASSCE exams. Dike precisely indicated that only $29 \%$ made a 5 credit grade in the subjects, including English and Mathematics.

The implication is that shortly, the nation may not have enough efficient manpower and would have no choice than to rely on the product and efficient manpower from other countries. Azuka (2013) stated that out of the major factors that influence students' achievement, teacher factors appear prominent. Students' poor performance in physics can be attributed to the lack of teachers' use of innovative teaching strategies in the twenty-first-century classroom (Ugwuanyi et al., 2020b). According to Ugwuanyi et al. (2020b), information communication technology (ICT) has a significant impact on students' achievement, especially in this twenty-first century world. This implies that the method of instruction adopted by the teachers largely determines the achievement of students in mathematics and physics. There is thus an urgent need for a paradigm shift in the methods that the contents of mathematics and physics are passed on to the students, especially in the twenty-first-century classrooms. 
International Journal of Engineering Research and Technology. ISSN 0974-3154, Volume 13, Number 7 (2020), pp. $1786-1794$

(C) International Research Publication House. https://dx.doi.org/10.37624/IJERT/13.7.2020.1786-1794

The use of Computer system especially Multimedia projection in teaching can be a solution to the poor performance of students in mathematics and physics. This is buttressed by Idahosa (2003) who opined that since students are very much interested and excited in the use of computer systems, it is necessary for mathematics and physics teachers to catch in the opportunity to use the machine as a teaching aid. Explaining further, Idahosa asserted that computer is highly adaptable in teaching vital parts of mathematics, most especially the elementary parts. It enables the students to grasp very well the major background concepts behind advanced mathematical calculations. Harbor-Peters (2001) highlighted a computer application as a computer program designed for a particular purpose. It could be adapted into an innovative technique of teaching mathematics, physics and indeed, any other subject. Thus, the computer application in the form of Computerassisted instruction (CAI) could be useful in helping students grasp the major concepts of mathematics and physics.

In the view of Oranu (2006), a well prepared and presented CAI or CAL package helps in the facilitation of the education process since interests of students are generated as they are actively involved in what they view on the screen. Moreover, they also carry out any instruction from the content developer on the same platform. The expected result is learning Mathematics with understanding. This reveals the beauty and elegance of Mathematics; which Agwagah (2007) called the aesthetic values of Mathematics. Hence, one way to expose the aesthetic values of mathematics is computer application in the teaching process. The use of multimedia projection, a subset of Information and Communication Technology (ICT), can enhance teaching and learning. Thus, every teacher must be ICT literate in all ramifications (Azare, 2019). Based on the foregoing, the researchers evaluated the impact of the CAI on improving mathematics and physics students' achievement within the theoretical framework of Richard Mayer's cognitive theory of multimedia learning.

\subsection{Theoretical background of the study}

This study was anchored on Richard Mayer's (1947) cognitive theory of multimedia learning which states that learning becomes effective when it comes from words and pictures than words alone. Mayer believes that deep learning by the students is achieved through sounds and images. Mayer stipulated that auditory and visual channels are important for processing information; each channel has a limited capacity and learning is an active process of filtering, selecting, organizing and integrating information based upon prior knowledge. According to Mayer, auditory and visual processes have influence on sensory, working and long term memory. This theory is related to the present study in that computer-assisted instruction consists of both visual and audio channel which can help the students to understand mathematics and physics concepts. This theory has been successfully utilised by Ejimonye et al. (2020a), Ejimonye et al. (2020a), Hamzat et al. (2017) and Edo (2017) to carry out similar studies.

\subsection{Review of related empirical studies}

A lot of studies have been conducted on the effects of computer assisted instructions on students' achievement as well as motivation in science and social science subjects. Abidoye and Omotunde (2015), Ayotola and Abiodun (2010), Gambari et al. (2014) and Salisu (2015) revealed a significant effect of computer-assisted instruction on students' achievement in different subjects excluding physics. King-Dow and ShihChuan (2015) found that animations contributed much to learning results of students' performance which uplifted students' physics concepts understanding. Hamzat et al. (2017) carried out a study on the effect of computer animation instructional package on students' achievement in practical Biology in Ilorin, Nigeria. The result revealed that the students in the experimental group who were exposed to the package had higher achievement scores than the students in the control group who were taught without the package. Edo (2017) carried out a study on the impact of computer animation learning on students' academic performance in Akwa Ibom State College of Education. Gambari et al. (2014) found that there was a significant effect of computer animation on the mean achievement scores of students in geometry. Falode et al. (2016) found that students taught Agricultural Science through computer animation instructional package performed better than their counterparts taught the same concept with the lecture method. Etim et al. (2016) found that computer animation learning course wave had a positive effect on student's academic performance.

Anigbo and Orie (2018) revealed that Microsoft PowerPoint Instruction Strategy had significant effect on students' achievement. Ezza, Alhuqail and Elhussain (2019) found that instructional technology significantly enhances learners' composing skills. Ruzicka and Milova (2019) found that the use of video analysis in providing feedback has a positive effect on the process of downhill skiing skills acquisition. Ugwuanyi et al. (2019a) found that flipped classroom instructional technology was effective in enhancing the achievement of physics students at both post-test and follow-up measurements. Ugwuanyi and Okeke (2020) found that computer-Assisted Instruction (CAI) had a significant effect on university students' achievement in physics. Ugwuanyi et al. (2019b) found that powerpoint presentation had a significant effect on students' achievement in physics and mathematics. Ugwuanyi et al. (2020b) found that animated powerpoint presentation (PPT) significantly enhanced the achievement of students in physics. Ejimonye et al. $(2020 \mathrm{a}, 2020 \mathrm{~b})$ found that $2 \mathrm{D}$ animation technique had significant effect on students' motivation and achievement in quantitative/mathematical contents of economics respectively. Ugwuanyi et al. (2020c) found that digital game-based learning significantly $(\mathrm{p}<.05)$ improved the achievement of primary school pupils at both the post-test and follow-up measures.

The forgoing indicated that computer based instructional strategies are effective in enhancing students' motivation to learn as well as their achievement in science and social science subjects. However, none of the studies reviewed studied the impact of computer-assisted instruction on students' achievement in mathematics and physics in Nigeria. Thus, this study evaluated the impact of CAI on students' achievement in 
International Journal of Engineering Research and Technology. ISSN 0974-3154, Volume 13, Number 7 (2020), pp. 1786-1794

(C) International Research Publication House. https://dx.doi.org/10.37624/IJERT/13.7.2020.1786-1794

mathematics and physics. The researchers hypothesized that computer-assisted instruction would have a significant impact on students' achievement mathematics and physics.

\subsection{METHODS}

\subsection{Design of the Study}

Pretest-posttest quasi-experimental, non-equivalent groups design was used for the study. This design has been recently used by Njoku et al. (2020), Ejimonye et al (2020a, 2020b), Igwe et al. (2020) and Ugwuanyi et al. (2019).

\subsection{Ethical Considerations}

The Faculty of Education, University of Nigeria approved this study through its institutional review board. The researchers strictly followed the ethical standard specifications of the American Psychological Association (APA, 2017).

\subsection{Participants}

A sample of 200 participants was used for the study. Purposive sampling technique was used in selecting participants in schools that have computer laboratories in Enugu State, Nigeria.

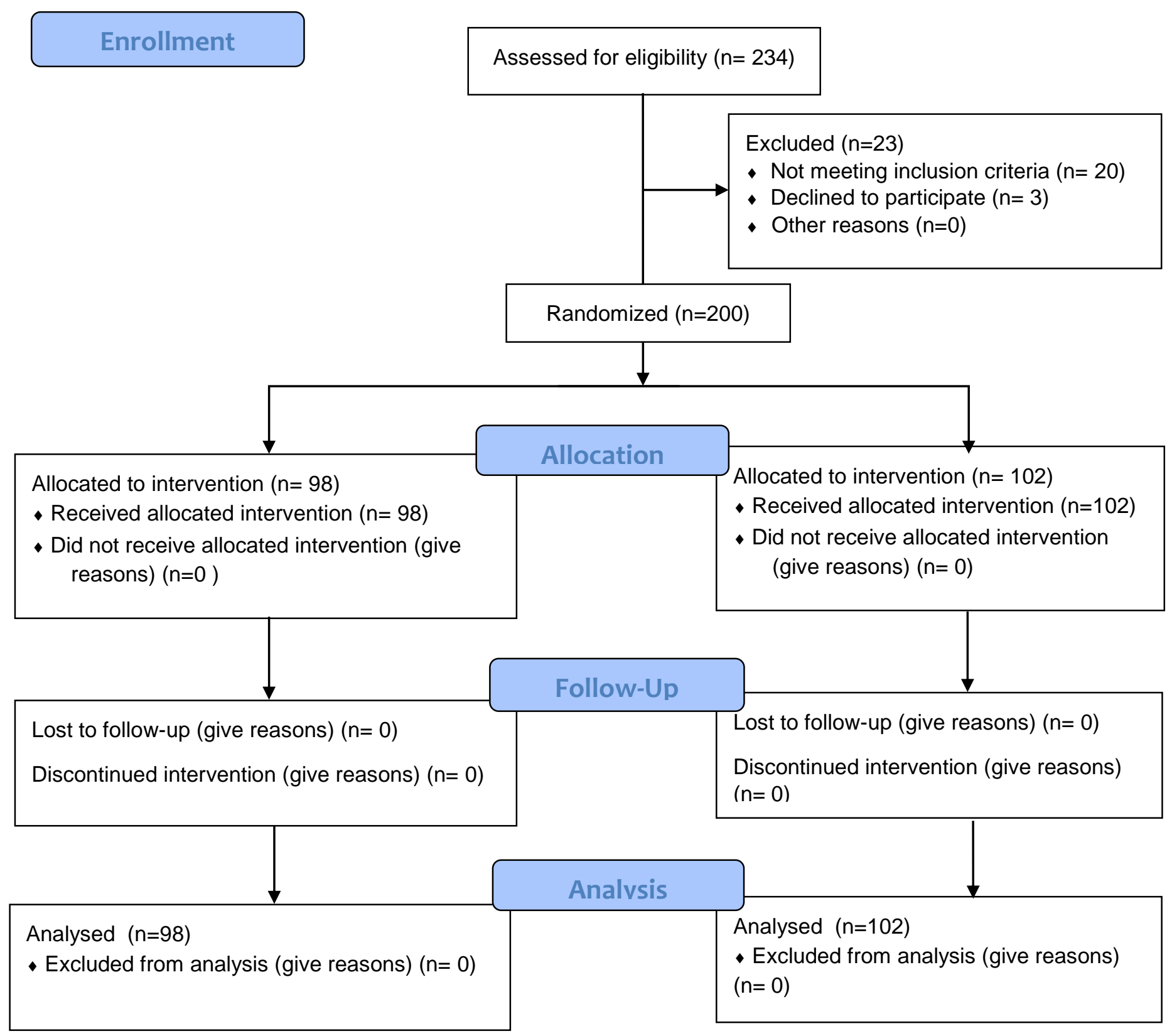

Figure 1: Flow Diagram of the Sampled Participants 
Table 1: Demographic characteristics of the participants

\begin{tabular}{lcccc}
\hline Variables & Categories & Experimental group & Control Group & Total \\
\hline Gender & Male & $48(48.98 \%)$ & $50(49.02 \%)$ & $98(49.00 \%)$ \\
& Female & $50(51.02 \%)$ & $52(50.98 \%)$ & $102(51.00 \%)$ \\
Total & $\mathbf{9 8}(100 \%)$ & $\mathbf{1 0 2}(100 \%)$ & $\mathbf{2 0 0}(100 \%)$ \\
Location & Urban & $51(52.04 \%)$ & $51(50.00 \%)$ & $102(51.00 \%)$ \\
& Rural & $47(47.96 \%)$ & $51(50.00 \%)$ & $98(49.00 \%)$ \\
& Total & $\mathbf{9 8}(100 \%)$ & $\mathbf{1 0 2}(100 \%)$ & $\mathbf{2 0 0}(100 \%)$ \\
Mean Age & & & \\
\hline
\end{tabular}

\subsection{Measures}

Mathematics achievement test (MAT) and Physics achievement test (PAT) were used to gather data. MAT consists of fifty (50) multiple-choice questions; all from the five main contents of Set namely - Definition of Set, Set Notations, Types of Set, Set operations and Venn diagrams. The MAT was developed from the listed contents by first constructing a table of a specification or test blueprint from the five main contents under the topic set. The objectives of the topic- SET in the SS1 Mathematics curriculum served as a guide in developing the questions. Since Set is used in different areas, 10 questions were set from each of the five contents under Set. The internal consistency reliability coefficient of the items of the MAT was estimated to be 0.78 using Kuder-Richardson formula 20, while the estimate of temporal stability was obtained as 0.83 using Pearson correlation.

PAT consists of 20-item multiple-choice questions of response options A, B, C \& D. PAT was developed by the researchers using test-blue print or table of a specification to ensure proper content coverage. PAT was face validated by three test development experts. The content validity of the PAT was determined using a table of specifications. An internal consistency reliability coefficient of the items of the PAT was estimated as 0.85 using Kuder-Richardson 20 (KR-20) formula, while the estimate of temporal stability was obtained as 0.79 using the Pearson correlation.

\subsection{Procedure}

Before the start of the treatment procedure, MAT and PAT were administered as a pretest to the two groups to collect baseline data for the study. The treatment commenced after the collection of the baseline data. The experimental group was exposed to multimedia projection in the form of computerassisted instruction (CAI) while the control group was exposed to the normal talk and chalk method of teaching. The contents of the instruction were drawn from Senior Secondary Mathematics and Physics core curricula of the Federal Ministry of Education. The two approaches for the Experimental and Control groups are identical in terms of content, basic instructional objectives, and content of evaluation. The only difference was in the instructional activities.

\subsection{Data Analysis}

The effectiveness of multimedia projection in enhancing the achievement of students in Mathematics and Physics was determined using analysis of covariance (ANCOVA). The effect size of the treatment was reported using Partial Eta squared. 


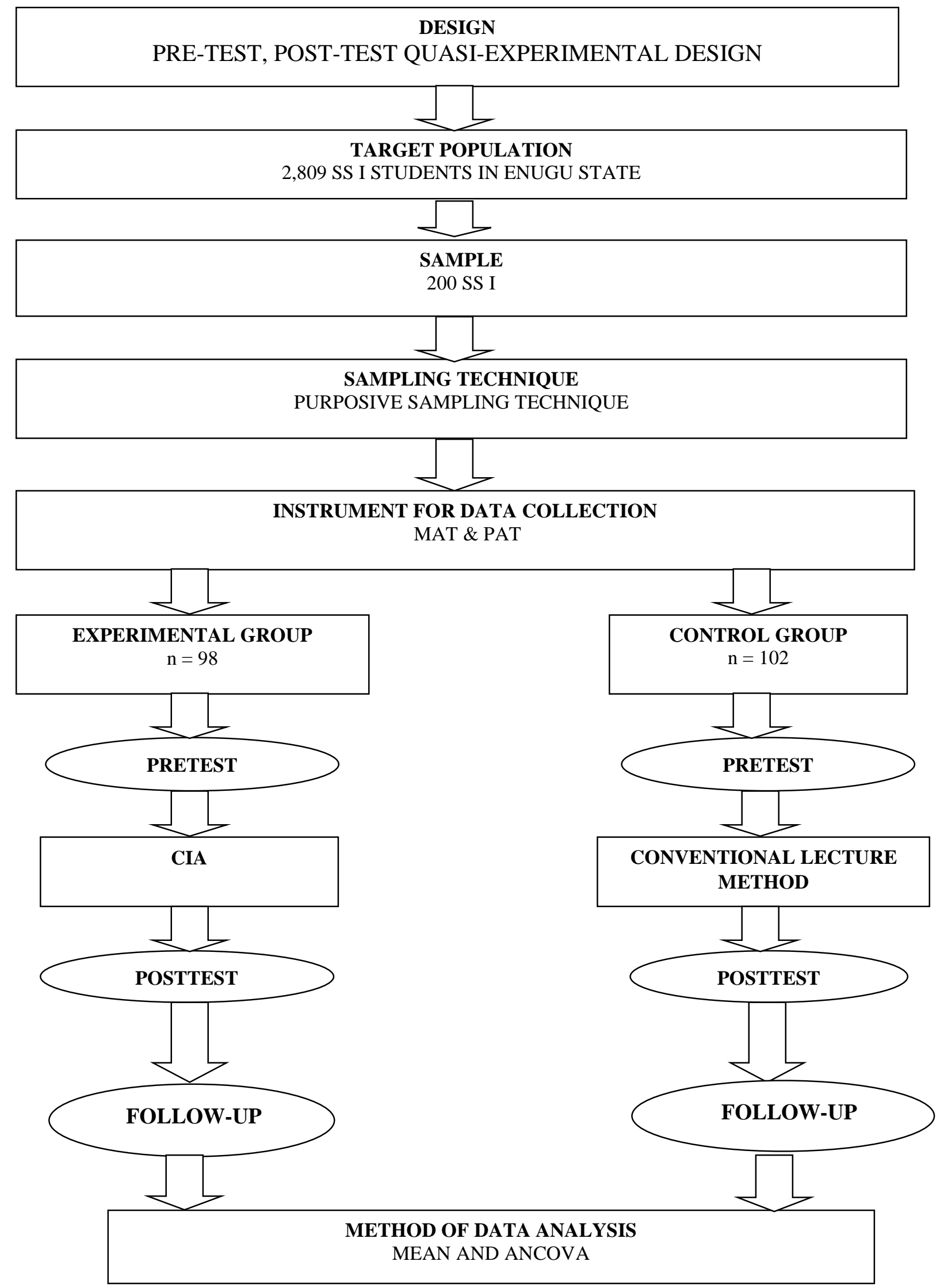

Figure 2: Schematic Representation of the Methodology 
International Journal of Engineering Research and Technology. ISSN 0974-3154, Volume 13, Number 7 (2020), pp. 1786-1794

(C) International Research Publication House. https://dx.doi.org/10.37624/IJERT/13.7.2020.1786-1794

\section{RESULTS}

Table 2: Analysis of variance of the effectiveness of CAI on achievement of students in Mathematics and Physics

\begin{tabular}{|c|c|c|c|c|c|c|c|}
\hline Time & Group & Mean (SD) & $\mathrm{F}$ & $\mathrm{p}$ & $y^{2}$ & $\Delta \mathrm{R}^{2}$ & $95 \% \mathrm{CI}$ \\
\hline \multirow{3}{*}{1 Pre-test } & Experimental & $24.10(1.38)$ & \multirow{3}{*}{0.95} & \multirow{3}{*}{.943} & \multirow{3}{*}{.012} & \multirow{3}{*}{.016} & \multirow{3}{*}{$0.11,1.89$} \\
\hline & Control & $24.40(1.59)$ & & & & & \\
\hline & Experimental & $63.88(2.07)$ & & & & & \\
\hline 2 Post-test & Control & $35.18(2.00)$ & 147.185 & .000 & .783 & .791 & $59.87,70.45$ \\
\hline \multirow[t]{2}{*}{3 Follow-up } & Experimental & $65.11(2.01)$ & \multirow[t]{2}{*}{151.041} & \multirow[t]{2}{*}{.000} & \multirow[t]{2}{*}{.799} & & \\
\hline & Control & $34.04(3.65)$ & & & & .801 & $72.87,95.66$ \\
\hline
\end{tabular}

PAT = Physics Achievement Test, Mean (SD) = Mean (Standard Deviation), $p=$ probability value, CI - Confidence Interval, $\eta^{2}$ - effect size, $\Delta R^{2}=$ Adjusted $R^{2}$

Table 2 reveals that the participants in experimental and control groups did not differ significantly in their Mathematics and Physics achievement at the pretest, $F(1,195)=.95, p=.943$, $\mathrm{\eta}^{2}=.012, \Delta \mathrm{R}^{2}=.016$. However, CAI had significant impact on Mathematics and Physics students' achievement after their exposure, $F(1,195)=147.185, p=.000, \mathrm{y}^{2}=.783, \Delta \mathrm{R}^{2}=.791$; and $F(1,195)=151.041, p=.000, \mathrm{y}^{2}=.799, \Delta \mathrm{R}^{2}=.801$. The results also showed that there was a significant interaction effect of time and group on the achievement of students in Mathematics and Physics, $F(2,195)=15.761, p=.000$, $\mathrm{y}^{2}=.467, \Delta \mathrm{R}^{2}=.521$. The nature of the interaction of treatment and time of measures is shown in Figure 3

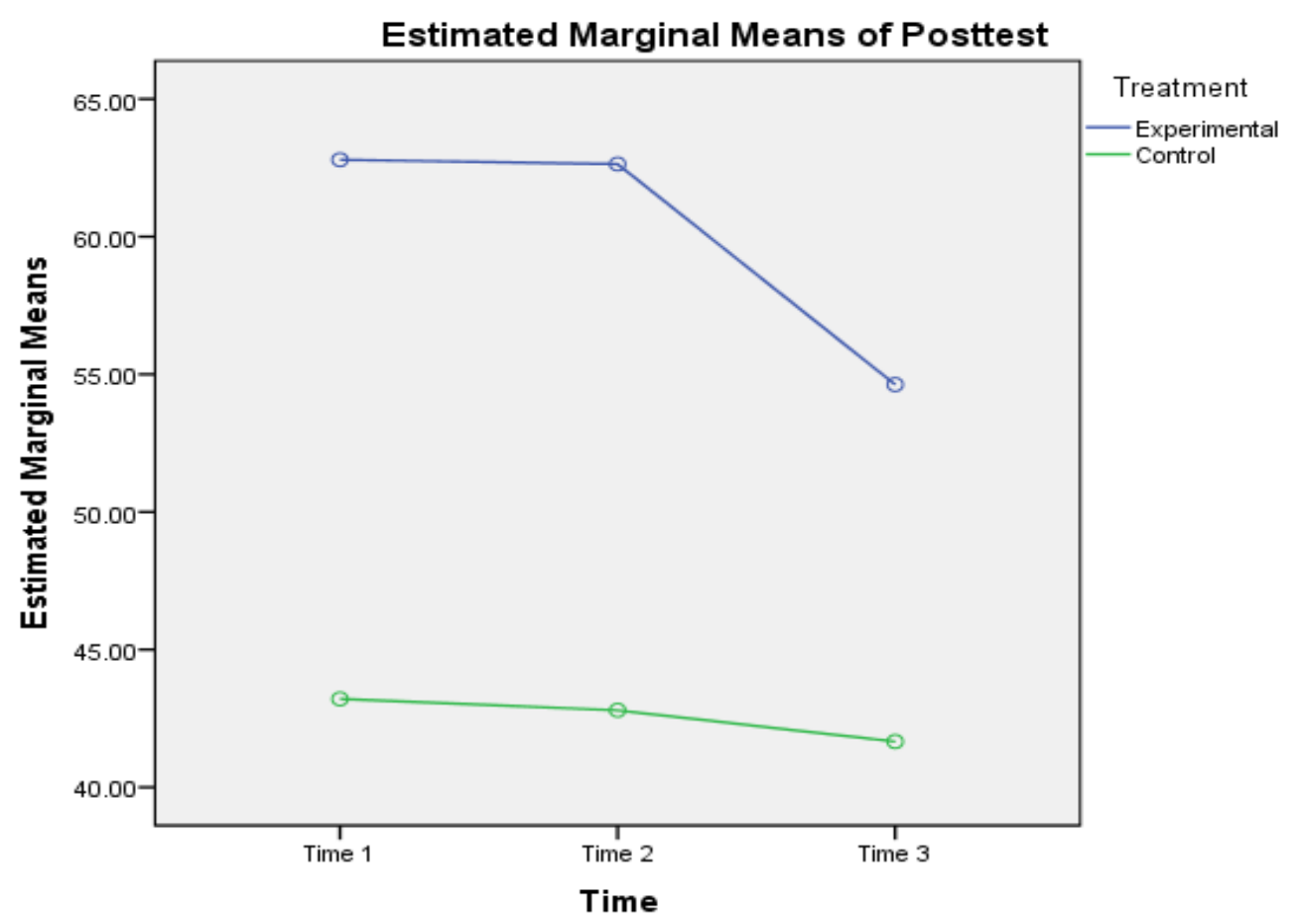

Covariates appearing in the model are evaluated at the following values: Pretest $=18.000 \mathrm{C}$

Figure 3: Interaction graph of time and treatment 


\section{DISCUSSION OF THE FINDINGS}

The findings of the study showed that CAI had a significant impact on students' achievement in Mathematics and Physics. This result goes to portray the interactive nature of CAI which may have activated the interest of the students and thus served as a motivator to learning by the students who participated in the experimental treatment. The improved interest and motivation by the experimental group may have accounted for the enhanced achievement of the students in Mathematics and Physics. This result is in line with Usman and Esaduwha (2007) who opined that e-learning is used to enhance and support learning for improvement in students' performance. This finding is also in conformity with Fakae (2014) who opined that e-learning subset such as ICT has greatly improved teaching and learning. According to Kadiri (2012), ICT is a powerful tool that can play instructional roles like making learners feel more relaxed to learn. The finding is also in agreement with Onah and Aguomuoh (2016) who found CAL, CAI, and CAD worthy computer-aided learning packages for promoting understanding of different subjects by students including mathematics. This is also in line with Azare (2019) who noted that the use of computers in teaching can best contribute to both teachers' knowledge and teaching effectiveness.

Buttressing the findings, Etim et al. (2016) found that computer animation learning course wave had a positive effect on student's academic performance. Falode et al. (2016) found that students taught Agricultural Science through computer animation instructional package performed better than their counterparts taught the same concept with the lecture method. Anigbo and Orie (2018) revealed that Microsoft PowerPoint Instruction Strategy had significant effect on students' achievement in schoool. Ezza, Alhuqail and Elhussain (2019) found that instructional technology significantly enhances learners' composing skills. Ruzicka and Milova (2019) found that the use of video analysis in providing feedback has a positive effect on the process of downhill skiing skills acquisition. Ugwuanyi et al. (2019a) found that flipped classroom instructional technology was effective in enhancing the achievement of students in physics. Ugwuanyi et al. (2019b) found that powerpoint presentation had a significant effect on students' achievement in physics and mathematics. Ugwuanyi et al. (2020b) found that animated powerpoint presentation (PPT) significantly enhanced the achievement of students in physics. Ugwuanyi and Okeke (2020) found that computer-Assisted Instruction (CAI) had a significant effect on university students' achievement in physics. Ejimonye et al. (2020a, 2020b) found that 2D animation technique had significant effect on students' motivation and achievement in quantitative/mathematical contents of economics respectively.

Ugwuanyi et al. (2020c) found that digital game-based learning significantly $(\mathrm{p}<.05)$ improved the achievement of primary school pupils at both the post-test and follow-up measures. Similar study found that flipped classroom instructional technique was more superior than the think pair share teaching strategy in enhancing the achievement and retention of physics students (Ugwuanyi et al., 2020d). Teachers can develop Computer Aided Learning (CAL) and use it to promote understanding of concepts in different subject areas. The researchers have, therefore, contributed to software development to enhance teaching and learning of different subjects. This finding has implication for Industrial Technical Education for the fact that improved achievement of students in Mathematics and Physics subjects at secondary education level will enable them to have interest in industrial technical education at higher education.

\subsection{Conclusion}

Multimedia projection in the form of CAI proved very effective in enhancing the achievement of students in Mathematics and Physics. Thus, effective use of CAI increases students' achievement in the subjects. Based on that, the researchers recommended among others that:

- Mathematics teachers should use CAI in teaching Mathematics and Physics concepts.

- The government should provide and equip Computer laboratories for effective implementation of CAI in the teaching of Mathematics and Physics concepts.

\section{REFERENCES}

[1] Abidoye, J. A. \& Omotunde, C. T. (2015). Effects of computer animation package on senior secondary school students' academic achievement in geography in Ondo state, Nigeria. Journal of teaching and teacher education, 3(2).

[2] Agwagah. U.V.N (2007). Aesthetic values of Mathematics. Journal of Mathematics Association of Nigeria.

[3] Akanbi, A.O., Omosewo, E.O., Ilorin, B.O.N. (2018). Teachers' characteristics and availability of laboratory as predictors of senior school students' performance in physics in Ilorin, Nigeria. Journal of Teacher Education and Educators, 7(1), 43-55.

[4] American Psychological Association (APA, 2017) Ethical Principles of Psychologists and Code of Conduct: American Psychological Association https://www.apa.org/ethics/code/.

[5] Amoo, S.A. (2002). Analysis of Problem encountered in Teaching and Learning of Mathematics in Secondary Schools. Abacus: Journal of MAN, 27 (1), 30-35.

[6] Anigbo, L. C \& Orie, M. J. (2018). Effect of powerpoint instruction on students' academic achievement in computer science (database management system) in Colleges of Education in Rivers State. Computer Engineering and Intelligent Systems, 9(1). www.iiste.org.

[7] Ayotola, A. \& Abiodun, S. (2010). Computer animation and the academic achievement of Nigerian senior secondary school students in biology. Journal of the Research Center for Education Technology (RCET), 6(2), 148-161.

[8] Azare, G. D. (2019). Information and Communication 
Technology. Foreword for SDGs Workshop, Kaduna: NTI.

[9] Azuka B.F. (2013). Attitude of Secondary Schools' Mathematics Teachers Towards the Teaching of School Mathematics in Nigeria. Journal of Mathematical Science Education, 2(1), 181-182

[10] Dike, G. (2013). Mass Failure in WASSCE: Daily Sun www.sunnewsonline.com. Friday, December 20, 2013 Vol. 10 No. 2779 page 6.

[11] Edo, E. E. (2017). Impact of Computer Animation Learning on students' academic performance in Akwa Ibom College of Education, AFAHA, NSIT . Multidisciplinary Journal of Research Development, 2 (26) , 1596-974X .

[12] Ejimonye, J.C., Onuoha, J.C., Ugwuanyi, C.S., Eneogu, N.D., Ugwuanyi, B.E \& Ogbuehu, S.N (2020a). Effectiveness of Two-Dimensional Animation Technique in Enhancing Students' Motivation in Quantitative Economics Concepts. International Journal of Future Generation Communication and Networking (IJFGCN), 13(1):27-38.

[13] Ejimonye, J.C., Ugwuanyi, C.S., Okeke, C.I.O., \& Nwoye, M.N. (2020b). Two-Dimensional Animation and Students' Achievement in Mathematical Economics: Implications for Science Teaching. International Journal of Engineering Research and Technology, 13(6), 1220-1230

[14] Etim, P.J, Itighise, A.E., \& Ema, I.B. (2016). Use of Educational Animation and Academic Performance of Business Studies Students in Akwa Ibom State. International Journal of Education , 4 (8) , 1948-547.

[15] Ezza, E-S., Alhuqail, E. \& Elhussain, S. (2019). Technology-based instructional intervention into an EFL writing classroom. Cypriot Journal of Educational Science, 14(4), 507-519. https://doi.org/10.18844/cjes.v11i4.3904.

[16] Fakae, B. B. (2014). The Computer: An indispensable millennium educational tool. Computer Education Research Journal (CERJ), 1(1)2.

[17] Falode, O. C., Usman, H., Ilobeneke, S. C., Mohammed, H. A., Godwin, A. J., \& Jimoh, M. A. (2016). Improving secondary school geography students' positive attitude towards map reading through computer simulation instructional package in Bida, Niger State, Nigeria. Bulgarian Journal of Science \& Education Policy, 10(1).

[18] Gambari, A. I., Falode, C. O. \& Adegbenro, D. A. (2014). The effectiveness of computer animation and geometrical instructional model on mathematics achievement and retention among junior secondary school students. European Journal of Science and Mathematics Education, 2(2), 127-146.

[19] Hamzat, A., Bello, G., \& Abimbola, I.O. (2017). Effects of computer animation instructional package on students' achievement in practical biology . Cypriot Journal of Educational Sciences, 4 (12), 218 -227.

[20] Harbor-Peters, V.F.A. (2001). Unmasking some Aversive Aspects of Schools Mathematics and strategies for averting them. Nsukka: University of Nigeria Nsukka.

[21] https://doi.org/10.18844/cjes.v11i4.1217

[22] Idahosa, G. (2003). Understanding elementary aspects of Mathematics to help in more complex ones. 2003 STAN proceedings.

[23] Igwe, J.N., Nzeadibe, A.C. \& Ugwuanyi, C.S. (2020). Education for inclusion: numeracy intervention in second chance education of market women in rural. African Population Studies, 34(1).

[24] Kadiri, G. C. (2012). The role of information and communication technology in language teaching and learning in University education. Journal of Liberal Studies, University of Nigeria, Nsukka, 15(1)1-2.

[25] King-Dow, S., \& Shih-Chuan, Y. (2015). Effective assessments of integrated animations to explore college students' physics learning performances. Procedia Social and Behavioral Sciences, 176, 588 - 595. https://doi.org/10.1016/j.sbspro.2015.01.514 ScienceDirect IETC 2014.

[26] Kolawole, S. A. (2012). Information and Communication Technology. Preface for MDG's project, Kaduna: NTI.

[27] Njoku, M.I.A., Nwagbo, C.R., \& Ugwuanyi, C.S. (2020). Effect of Peer Tutoring and Peer-Led Team Learning on Students' Achievement in Biology. International Journal of Database Theory and Application (IJDTA), 13(1),1-10. https://doi.org/10.33832/ijdta.2020.13.1.01.

[28] Onah, E. N. \& Aguomuoh E. E. (2016). Level of Utilization of Computer Aided Design, Instruction and Learning by Computer Education Lecturers and Technical Instructors in the Colleges of Education in South East Nigeria. Journal of Technical Vocational Education, Training and Research. 1(2), 90 - 100.

[29] Onah, E.N. (2004). Effects of Indices Card and Board(INDICAB) - Game on the Achievement and Interest of students in Indices. Unpublished M.Ed Thesis, Department of Science Education, University of Nigeria

[30] Oranu, P. (2006). Mimeograph on Computer Aided Educational Technology - VTE 562, University of Nigeria Nsukka.

[31] Ruzicka, I. \& Milova, J. (2019). Increasing the efficiency of motor learning with the help of video analysis. Cypriot Journal of Educational Science, 14(4), 723-730.

[32] Salisu, A. (2015). Impact of animated-media strategy on achievement, retention and interest among secondary 
school geography students in weather concepts, Kastina State, Nigeria (Unpublished Masters thesis). Department of Science Education, Ahmadu Bello University, Zaria, Nigeria.

[33] Ugwuanyi, C.S., Elejere, U.C., Gana, C.C., Macmillan, J., Abraham, I., Ugwuanyi, E. C., Ezeugwu, E. E. \& Ogili, I. S. (2019c). Assessment of the efficacy of practical activities on the interest and achievement of senior secondary school students in physics. Journal of CUDIMAC, 6(1), 1-8

[34] Ugwuanyi, C. S., Okeke, C. I. O., Nnamani, P. A., Obochi, E. C. \& Obasi, C. C. (2020b). Relative effect of animated and non-animated powerpoint presentations on physics students' achievement. Cypriot Journal of Educational Science. 15(2), 282-291. https://doi.org/10.18844/cjes.v15i2.4647

[35] Ugwuanyi, C.S., Nduji, C.C., Gana, C.S., Nwajiuba, C.A., Ene, C.U., Okeke, A.O., Eseadi, C., Okeke, C.F. (2019a). Effectiveness of flipped classroom instructional technology model in enhancing students' achievement in physics. International Journal of $u$ - and e-Service, Science and Technology, 12(4): 37-46.

[36] Ugwuanyi, C.S., Nduji, C.C., Elejere, U.C., \& Omeke, N.E. (2020d). Effect of Flipped Classroom and Think Pair Share Strategy on Achievement and Retention Among Senior Secondary School Physics Students. International Journal of Sciences: Basic and Applied Research (IJSBAR), 52(2), 136-148. https://www.gssrr.org/index.php/JournalOfBasicAndA pplied/article/view/11250/5681

[37] Ugwuanyi, C. S., Okeke, C.I.O. \& Asomugha, C.G., (2020a). Prediction of learners' mathematics performance by their emotional intelligence, selfesteem, and self-efficacy. Cypriot Journal of Educational Science. $\quad$ 15(3), 492-501. https://doi.org/10.18844/cjes.v\%vi\%i.4916

[38] Ugwuanyi, C.S., \& Okeke, C.I.O. (2020). Enhancing University Students ' Achievement in Physics using Computer-Assisted Instruction. International Journal of Higher Education 9(5), 115-124. https://doi.org/10.5430/ijhe.v9n5p115

[39] Ugwuanyi, C.S., Okenyi, E.C., Ezema, V., \& Amoke, C. (2020c). Effect of digital game-based learning on achievement of primary school pupils in sciences in Enugu State, Nigeria. Journal of Educational Research on Children, Parents \& Teachers, 1(1), 35-44.

[40] Ugwuanyi, C.S., Ugwuanyi, C.C., EzenwaNebife, D.C., Gana, C., Ene, C., Oguguo, B.C., Ikeh, F.E., Okeke, A.O., Nwoye, M.N., Obi, C.N., Anyaegbu, C. \& Agah, J.J. (2019b). Assessment of the efficacy of information and communication technology tool on achievement of students in physics and mathematics: A case of repeated $\mathrm{m}$ easures. Journal of Engineering and Applied $S$ ciences, 14(13), 4541-4546.
[41] Usman, E. O. \& Esaduwha, O. S. (2007). Prospects and Challenges of E-learning in Tertiary Education: Designing and Development of E-learning in Education and Training. STAN Proceedings of the 50th Anniversary Conference. HEBN Publishers Plc.

[42] Usman, K.O. (2002). The need to Retrain in-service mathematics teachers for the attainment of the objectives of Universal Basic Education (UBE). Abacus: The Journal of the Mathematical Association of Nigeria, 27(1)37-44.

[43] W.A.E.C (2006) West African Senior School Certificate Examination May/June 2006, Chief Examiners' Report Lagos, Nigeria.

[44] W.A.E.C (2007) West African Senior School Certificate Examination May/June 2007, Chief Examiners' Report Lagos, Nigeria.

[45] W.A.E.C (2012) West African Senior School Certificate Examination May/June 2012, Chief Examiners' Report Lagos, Nigeria. 